\title{
WOODROW WILSON'S USE OF THE NON-RECOGNITION POLICY IN COSTA RICA
}

\begin{abstract}
$\mathrm{O}$ $F$ all Woodrow Wilson's foreign policies, none is more deserving of criticism than his non-recognition policy. This policy, initiated by the President within a week after his accession to office on March 4, 1913, in response to the news of violent revolutionary disturbances in Mexico and Nicaragua, was primarily predicated on Wilson's assumption that the best way to prevent the recurrence of revolutions in Caribbean nations would be to warn all would-be revolutionists that they could expect no political or financial support from the United States. Ultimately he hoped that he could end the threat of revolution and induce all Latin American nations to abide by constitutional and democratic forms of government. Hence, in a press statement on March 11, 1913, he proclaimed:
\end{abstract}

Cooperation is possible only when supported at every turn by the orderly processes of just government based upon law, not upon arbitrary or irregular force. We hold, as I am sure all thoughtful leaders of republican government everywhere hold, that just government rests always upon the consent of the governed, and that there can be no freedom without order based upon law and upon the public conscience and approval. We shall look to make these principles the basis of mutual intercourse, respect and helpfulness between our sister republics and ourselves. ${ }^{1}$

Wilson's non-recognition policy thus grew out of his belief that all nations could in time be prepared to take part in a brotherhood of democratic nations which could bring peace to the world. His idealistic dream was doomed to failure; too many obstacles stood in the way of such a utopian world. Not least among these barriers was Wilson's presumption that the Anglo-American systems of democratic government were the best possible bases for his brotherhood of nations and that all nations were ready for or desired them. Just as important an obstacle was Wilson's duty to provide for the defence of the United States in a world largely governed by national self-interest. It was this latter fact that placed Wilson, when he learned of the revolutionary disorder in Nicaragua and Mexico, two nations dangerously

\footnotetext{
1 For a good collection of Wilson's early policy statements, see E. E. Robinson and V. J. West, The Foreign Policy of Woodrow Wilson (New York, 1918); on his reaction to the revolutions, see David F. Houston, Eight Years with Wilson's Cabinet (2 vols.; Garden City, N. Y., 1926), l, 44.
} 
near both the United States and the soon-to-be completed Panama Canal, on the horns of a dilemma: either he would have to await the voluntary cooperation of each nation to preserve internal stability or else he would have to intervene by force of arms. As a solution, he chose a middle course by promulgating a non-recognition policy to apply non-violent pressure on revolutionary leaders. This policy, however, was contrary to the general international principle that de facto recognition of a relatively stable government was the only effective way to deal with revolutionary regimes.

Nevertheless, despite admonitions against the use of this policy from his advisers in the State Department, Wilson proceeded to implement the non-recognition policy not just in Mexico but in Costa Rica. His use of the policy in Mexico is well known, but his effort in Costa Rica is not. In Costa Rica, as in Mexico, his policy, though formulated on what he considered as a moralistic and beneficial basis, was to rebound with harmful effects on both that country and the United States.

When Wilson came to power in 1913, he probably gave little or no thought to Costa Rica. Nor did he have to. His predecessors, Presidents Theodore Roosevelt and William Howard Taft, had secured a large measure of peace and stability in the Caribbean region by their various power policies. They had instituted financial protectorates to insure the payment of foreign debts and to remove the financial incentive to revolutionaries. When this failed, they had sent battleships to trouble-spots to show that American power was present and also to make available friendly offices when necessary.

Costa Rica had been unique among its Caribbean neighbors in that it had generally been able to stand on its own feet. Many explanations have been offered as to why Costa Rica was relatively stable; the most convincing is that Costa Ricans were economically more favored than their neighbors. Twenty-five years earlier, the Republic had been put on the road to prosperity through the work of Minor C. Keith, one of the principal founders of the United Fruit Company. Keith had built a railroad network and a banana empire. The opportunities of the country induced him to remain, making it the center of his activities in Central America. To insure the nation's financial and political stability, he had assumed, of course with a reasonable profit, one-half the bonded indebtedness of the country. In 1911 he had arranged a loan with American bankers for the government which was based upon the sound security of the customs receipts and the internal revenues. His company had also financed a large part of the country's internal improvements, 
in particular, branch lines for the railroad, harbor facilities, and highways. ${ }^{2}$

A second possible explanation as to why Costa Rica was stabler than its neighbors is that the people were politically more sophisticated. In part, this was due to better educational facilities. But, in a larger degree this political peace rested upon the influence of Keith, certain other American investors in agriculture and mining, English promoters like Walter Ford, and some Costa Ricans who had a vested economic interest. Political power was mainly based upon a web of family alliances, and both Keith and Ford had married into the most influential families. Factionalism existed between the families, but most election campaigns were highlighted only by vituperation and name-calling. After an election, politics subsided. Corruption in office appeared to be negligible, and the revolutionary habit, so characteristic of many Latin American nations, did not seem to prevail.

Not until December, 1913, did the political situation undergo a significant change, which was to reverberate throughout the decade. In a hotly contested election, none of three candidates secured a majority of the popular vote. Alfredo González Flores finally won the votes of a loose coalition in Congress, and the opposition was so embittered that it henceforth viewed the election as the hallmark of political corruption. ${ }^{3}$ In September, 1914, the first overt manifestation of this opposition occurred when Colonel Prestenary, an aide of former president Ricardo Jiménez, attempted a coup d'état. The significance of the Prestenary revolt was that it revealed the nature and the extent of the opposition to the González government. Prestenary was associated not only with the liberal Luis Anderson, a statesman and a friend of Elihu Root, but also with Rafael Iglesias y Castro, a brother-in-law of both Keith and Ford. Though the American minister, Edwin J. Hale, an inexperienced political appointee of Secretary of State William Jennings Bryan, did not note the possible link between Keith and Prestenary, he was so informed by the González government. Ostensibly, Anderson had taken part in the affair only because he had

\footnotetext{
${ }^{2}$ Charles Wilson, Empire in Green and Gold (New York, 1947), pp. 36 ff.; and C. D. Kepner and J. H. Soothill, The Banana Empire (New York, 1935), pp. $40 \mathrm{ff}$.

${ }^{3}$ For Costa Rican politics, see Dana G. Munro, The Five Republics of Central America (New York, 1918) and Chester L. Jones, Costa Rica and Civilization in the Caribbean (Madison, 1935); also three dispatches of Chargé Mitchall Langhorne to William J. Bryan, dated May 27, 1913, July 15, 1913, and May 9, 1914, Department of State Papers, Decimal File (hereafter cited as D.S. File), 818.00/42, 44, and 45, National Archives.
} 
dreams of a confederation of all the Central American nations which he hoped Prestenary would carry through. In any case, the revolt failed, although it may have been the prelude for the revolutionary upheaval later on. ${ }^{4}$

The Wilson administration did not interfere in this minor affair, although the State Department kept itself well informed. Actually, in the first year of his administration, Wilson was trying hard to permit the Latin American nations to handle their own affairs. In Mobile, Alabama, on October 27, 1913, he renounced the selfish policies of his predecessors and proclaimed that the United States would seek to be the "friend and champion [of Latin American nations] upon terms of equality and honor." Even though Costa Ricans, along with most Latin Americans, welcomed this promise, they were reluctant to accept it entirely.

The conflict of Wilson's ideals with his nation's interests soon became apparent in his Costa Rican relations when he negotiated the Nicaraguan Canal Treaty. This treaty seemed necessary both to provide funds for chaotic Nicaragua and to assure the United States a monopoly of the isthmian routes. But at the same time the Canal Treaty provoked Costa Rica to protest that the treaty violated its navigational and territorial rights on the San Juan River which bordered the two countries. Since much of the isthmian route was to follow this river, the United States found itself in a dilemma wherein the approval of the treaty might mean violating Costa Rican sovereignty. Costa Rica, to make matters worse, pressed its suit against Nicaragua before the Central American Court of Justice and was upheld. When Wilson proceeded to disregard this decision, because he hoped the Canal Treaty would save Nicaraguan finances, he struck a serious blow at his promise of friendship and brotherhood. To many Costa Ricans, Wilson's attitude seemed but a new aspect of American imperialism. ${ }^{5}$

\footnotetext{
${ }^{4}$ Hale to Bryan, September 30, 1914, D. S. File 818.00/46. Dana Munro, a Latin American authority and later a member of the Latin American Division in Harding's administration, was then studying in Central America. Because he opposed Wilson's Mexican policy and spoke freely on Costa Rican political affairs, Hale disapproved of him. Munro believed that Costa Rican political tranquillity rested upon the fact that land ownership was widespread and that the majority of whites were less susceptible to revolution. Hale to Bryan, October 30, 1914, D.S. File 818.00/47.

${ }^{5}$ Costa Rican claims rested upon the Cañas Jérez Treaty of 1858 and the Grover Cleveland Award based upon that treaty. Wilson may have appeared to disregard Costa Rican claims, but in private he sincerely hoped to compensate it, once Nicaraguan affairs were settled. Wilson to Bryan, March 11, 1915, Bryan-Wilson Correspondence, National Archives.
} 
Another instance in which Wilson interfered in Costa Rican affairs was his move to prevent the powerful oil company owned by Lord Cowdray of Great Britain from obtaining oil concessions in that country. Because he feared British inroads in this nation so near the Panama Canal, Wilson persuaded Costa Rican officials to turn down the request of the Cowdray firm. The London Daily Mail charged that the State Department was exercising undue influence in Costa Rica. Whether Costa Rica was offended by the affair is not known, but at least the incident showed that Wilson was taking a keen interest in Central American countries because of the need to defend the Panama Canal. ${ }^{\circ}$ Increasingly Wilson's diplomacy reflected a transition from idealism to realism as the Caribbean area, particularly the Panama Canal, appeaped to be threatened by foreign powers.

Except for these incidents, official relations in the early years showed some signs of friendship. Costa Rica signed one of Bryan's " coolingoff " treaties on February 13, 1914. " That country also agreed to extend the 1910 arbitration convention, for the settlement of minor disputes, in March, 1914. ${ }^{8}$ During 1915 and 1916, official relations appeared so promising that President González, in a congressional message on May 2, 1916, announced that, save for resolving the Nicaraguan Canal Treaty question, then before the Central American Court, and the dispute over the White Award, relations might become quite cordial. ${ }^{9}$

Nevertheless, official professions of friendship notwithstanding, public suspicion toward the American government continued to exist. When, for example, La Información reprinted articles on Wilson's Mexican policy from the New York Tribune, the Costa Ricans, still incensed over the Nicaraguan issue, were aroused to anger over the alleged racial

- Hale to Bryan, November 11, 1913; Samuel T. Lee (Consul at San José) to Bryan, November 22, 1913; John B. Moore to Hale, December 2, 1913, Papers Relating to the Foreign Relations of the United States (hereafter cited as Foreign Relations) (Washington, 1920), pp. 865-866; The Nerw York Times, December 13, 1913, 2: 4.

${ }_{7}$ These treaties were designed to set into motion arbitration machinery to settle a dispute within a year. Meanwhile the two contending nations could not resort to force of arms and would have, it was anticipated, "cooled-off" while awaiting the arbitration decision. Foreign Relations, 1914, pp. 171-173.

${ }^{8}$ William Malloy, Treaties, Conventions, International Acts, Protocols, and Agreements between the United States of America and Other Powers, 67th Congress, 4th session, document number 348 (Washington, 1923), pp. 2547-2548.

${ }^{9}$ For this speech, see Hale to Lansing, May 2, 1916, Foreign Relations, 1916, p. 217. The White Award involved the decision rendered by Chief Justice Edward D. White on a boundary dispute betwen Costa Rica and Panama. Because Panama challenged the merit of the award which favored Costa Rica, Costa Rica was seeking American good offices to uphold the White Award: 
bias of Wilson toward Latin Americans. Because Wilson had been portrayed by the newspapers as "changeable and voluble" in his dealings with "inferior" peoples, he was as distrusted as any yanqui. ${ }^{10}$ That this suspicion was justified seemed apparent when Wilson applied his non-recognition policy to Costa Rican internal affairs in 1917.

On January 17, 1917, Federico Tinoco, minister of war for González, charged dictatorship and overthrew the government in a well executed coup d'état. González, Máximo Fernández, the president of the congress, and members of the cabinet fled to the American legation for protection. González requested American intervention while Minister Edwin J. Hale, apparently in a quandary, sought advice from Washington. ${ }^{11}$

Unfortunately, Hale found that he could not use official communications and had to request the use of the United Fruit Company wireless station. Although the company agents refused the minister the use of the wireless, they did see fit to inform the State Department not only that the revolution was a popular movement but also that the provisional government established by Tinoco ought to be recognized. The agents added that the United Fruit Company had had nothing to do with the coup d'état. ${ }^{12}$ Whether the company was in fact innocent became thereafter an important problem for the State Department. ${ }^{13}$

Hale's dispatches seemed to confirm the company's opinions on the succcess of Tinoco. Hale reported that Tinoco had appointed a cabinet and arranged for elections both for the presidency and for delegates to a constitutional convention. The only problem, he believed, was the Tinoco government's propaganda which was inciting the public to oppose an American intervention if it came. ${ }^{14}$ Hale favored recognition because a "popular" de facto government had been formed,

\footnotetext{
${ }^{10}$ Hale to Lansing, September 22 and November 4, 1916, D. S. File 818.00/49 and 51; Amasa Thornton to Lansing, December 4, 1916, Robert Lansing Papers, Library of Congress.

${ }^{11}$ Hale to Lansing, January 27, 1917, Foreign Relations, 1917, p. 301; Jacinto López, La Caida del Gobierno Constitucional en Costa Rica (New York, 1919), p. 9; Carlos Monge Alfaro, Historia de Costa Rica (San José, 1959), pp. 254-255; Jones, Costa Rica and Civilization in the Caribbean, p. 26.

${ }^{12}$ State Department Memorandum by Jordan H. Stabler, January 29, 1917, D. S. File $818.00 / 81$.

${ }_{13}$ William Sulzer to Lansing, January 30, 1917, D. S. File 818.00/62; Samuel Untermyer to Lansing, January 31, 1917, D. S. File 818.00/64.

${ }^{14}$ Hale to Lansing, January 30, 1917 (sent through Benjamin Jefferson in Managua), D. S. File $818.00 / 61$.
} 
although he also paradoxically reported that González had been overthrown because of his "excellent land and income measures" which had "excited the hostility of the powerful privileged classes." Why, then, did the "public" approve? This question Hale never fully answered; nor could Tinoco or his supporters really justify the coup d'état. ${ }^{15}$

In any event, whatever the motive behind the coup d'état, Wilson had a pre-determined policy towards revolutions which he now applied to Costa Rica. When he was informed of the revolution by Secretary of State Robert Lansing, he reportedly became very excited and stressed that the United States would act to deny any succor to the revolutionists. Later, Lansing, formerly a reputable international lawyer,' recalled that he personally was strongly opposed to the unorthodox policy which he defined as follows: "It was an assumption by the President of a right to determine who should not rule another country. In a way it was a species of overlordship." He nonetheless dutifully followed, for the " time being," the President's dictum, though he grew increasingly concerned because the policy conflicted with international practice and might possibly produce a harmful effect on hemispheric solidarity in the war. $^{16}$

Lansing's worst fears were shortly realized, for he was soon beset with all the repercussions of the revolution. Both Rafael Oreamuno, the González appointee as secretary of the Costa Rican legation, and González himself, then on his way to the United States, constantly reiterated both publicly and officially their concern lest recognition be too hastily extended. ${ }^{17}$ Lansing had no intention of so doing, for upon learning that the American legation was too friendly with the United Fruit Company, he again ordered Hale to take no steps whatever towards recognition. ${ }^{18}$ Furthermore, he had already begun to inquire into Tinoco's background and the revolutionary situation in order to forestall the dictator's future moves.

That Tinoco had obviously been preparing the revolution for some

15 Hale to Lansing, January 30, 1917, Foreign Relations, 1917, p. 304; González may have aroused some popular resentment when in his struggle with the powerful classes he resorted to restrictions on press and speech, but this was hardly enough to warrant a revolution. Jones, Costa Rica and Civilization in the Caribbean, p. 27.

I6 Robert Lansing, $W$ ar Memoirs (Indianapolis, 1935), pp. 308-309.

17 Rafael Oreamuno to Chandler P. Anderson, counselor of Costa Rica, February 2, 1917, Chandler P. Anderson Papers, Library of Congress.

18 Lansing to Hale, February 5, 1917, Foreign Relations, 1917, p. 305. 
time necessarily implied financial support. Whether this support came from the United Fruit Company, which was suspected of nefarious political activities, became the question of the hour. According to Jordan Stabler of the Latin American Division, not only was there the "evident desire" of the company to urge recognition of Tinoco, but also Minor Keith was related by marriage to the dictator. "It would seem," he concluded, "that the Fruit Company must at least have known about Tinoco's plot, if it had not aided and abetted him in it." To add further complications to the Department's stand, Stabler observed that Tinoco's neighbors, El Salvador, Honduras, Nicaragua, and Guatemala, were uneasy. Stabler's recommended solutions were the ordering of the United Fruit Company to desist from interfering in Central American politics and the sending of a firm notice of the nonrecognition policy to the "unscrupulous" Tinoco. ${ }^{10}$

Lansing and Wilson agreed that a strong statement of policy was essential and that such action, as Wilson put it, be taken as to give the company " immediate pause." Wilson even intended to go beyond the secretary in making the American policy irrevocable:

I think the telegram to San Jose ought to be made a little stronger. It ought to instruct the Minister to say to Tinoco that no government set up by him will be recognized, and no contracts by any citizen of the United States with such a government will be recognized by this Government as valid. We cannot be too explicit or too downright..

Lansing sent an instruction of this purport to Hale and also informed Tinoco's neighbors that the United States would not extend recognition since "illegal acts of this character tend to disturb the peace of Central America and to disrupt the unity of the American continent." ${ }_{21}$ Only El Salvador, already aggrieved over the Nicaraguan Canal Treaty, was soon reconciled with its neighbor and opposed Wilson's policy by recognizing Tinoco. ${ }^{22}$ The Salvadoran semi-official newspaper, $\mathrm{La}$ Prensa, called the non-recognition policy a farce. ${ }^{23}$

${ }^{19}$ Lansing to Wilson, February 7, 1917, D. S. File $818.00 / 105 \frac{1}{2}$.

${ }^{20}$ Wilson to Lansing, February 7, 1917, Papers Relating to the Foreign Relations of the United States: The Lansing Papers, 1914-1920 (hereafter cited as The Lansing Papers) (2 vols.; Washington, 1939-1940), II, 518.

${ }^{21}$ Lansing to William R. Leavell, February 9, 1917 (mutatis mutandis to Tegucigalpa, San Salvador, and Managua), Foreign Relations, 1917, p. 306. The British ambassador was also informed of this policy and Britain followed the American point of view in the affair. William Phillips to Stabler, February 17, 1917, D. S. File 818.00/77.

${ }_{22}$ State Department Memorandum by Stabler, February 7, 1917, D. S. File 818.00/92.

${ }^{23}$ Boaz W. Long to Lansing, February 17, 1917, D. S. File 818.00/97. 
The Wilson administration was determined to pursue the policy, despite critics at home and abroad. ${ }^{24}$ Even Lansing granted the merits of the policy in that the Tinoco revolution was not truly above suspicion in its origins. After the secretary interviewed González, he found him to be a "real progressive in his ideas" and to be working unselfishly to re-establish a constitutional government. Wilson agreed to see González if only to "make an impression in certain quarters which it is desirable to make." ${ }^{25}$

In other respects, the administration strove to undermine the revolution. Both the United Fruit Company and Central Americans were again informed that neither would Tinoco be recognized nor would any recognition be given to any economic concessions he might grant. ${ }^{26}$ The Department dealt only with the González legation, and despite Tinoco's efforts to gain entry for his representatives, the dictator's overtures were bluntly rejected. Even when Tinoco proposed resigning in favor of Manuel Aguilar, a person he thought to be more suitable to the United States, he was ignored. ${ }^{27}$ Though Tinoco also had strong intermediaries, as had Huerta in Mexico, Washington was indifferent to their pleas. ${ }^{28}$ The State Department, in fact, began a deliberate campaign to ferret out all of Tinoco's agents and supporters in the United States and Central America. ${ }^{29}$

"Watchful Waiting," as in Mexico, was thus being applied to the fullest extent in Costa Rica. Tinoco's refusal to abide by Wilson's policy had brought American wrath down upon him. Counselor Frank Polk informed Chandler P. Anderson, the American legal counsel of Costa Rica, that the only way to end the deadlock would be the selection of another president by the various factions-the same solution earlier offered to the Mexicans. ${ }^{30}$ Even the British, after having

24 Entry of February 15, 1917, Anderson Diary.

${ }^{25}$ Lansing to Wilson, February 19, 1917; Wilson to Lansing, February 20, 1917, The Lansing Papers, II, 519.

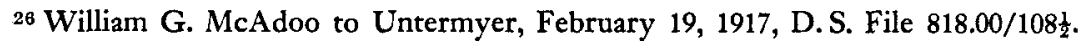

${ }^{27}$ Lansing to Hale, February 22, 1917, Foreign Relations, 1917, p. 308; Anderson to Polk, February 21, 1917, Frank Polk Papers, Yale University Library; Stabler to Lansing, March 3, 1917, D.S. File 818.00/89; Manuel Castro Quesada to Lansing, February 28, 1917, Foreign Relations, 1917, pp. 309-312.

${ }^{28}$ Among Tinoco's intermediaries were the minister of foreign affairs Carlos Lara, ex-president Cleto González Víquez, and Manuel Echeverría, a member of the Central American Court. Hale to Lansing, March 3, 1917, D. S. File 818.00/111.

29 State Department Memorandum by Warren D. Robbins, March 7, 1917, D. S. File $818.00 / 108$.

${ }^{30}$ Entry of March 10, 1917, Andersón Diary. 
incurred Wilson's ill will in Mexico, now deferred to the United States, despite the fact that their security-conscious minister to Costa Riva and Panama, Sir Claude Mallet, strongly urged support of Tinoco rather than the pro-German González. ${ }^{31}$

Wilson's non-recognition policy soon began to undermine even further Tinoco's initially weak economy and financial structure. Coming hard upon the heels of the German submarines' blockade of Costa Rica's European trade, Wilson's policy intensified the economic distress. González's minister to the United States, Manuel Castro Quesada, informed Lansing that the economic situation was so precarious that, should the European trade continue to be blocked and should the United States continue to withhold recognition, the fall of Tinoco was imminent. $^{32}$ By March, Minister Hale reported that the exchange rate for the American dollar indicated a crippling inflation and that the "economic condition of Costa Rica which is approaching disaster, with starvation for the people " showed the paralysis of the Tinoco government. More importantly, Hale observed, Tinoco's revenues were so small that he had been unable to pay his debts to his supporters and that counterrevolutionary talk was in the air. To forestall this eventuality, which would add further woes to the people, Hale advised Washington that the distress could be considerably alleviated if the United States, the most important customer, raised its restrictions on concessions and contracts.

Hale received no response and, though he continued to plead in behalf of the people, even he realized, as had Ambassador Henry Lane Wilson in Mexico, that when $W$ ashington did not want a legation to recognize or to support a government, the representative had to acquiesce. Thus, not only were his subsequent reports on the revolution cautiously and objectively phrased, but also his dispatches contained explanations of his earlier pro-Tinoco views and apologies for his outspoken assistant, John Keith, nephew of Minor C. Keith. ${ }^{33}$

Wilson's inflexible stand, however, was not unopposed. Leo S. Rowe, an eminent Latin American authority recently appointed to the Latin American Division and later Director General of the Pan American

\footnotetext{
${ }^{31}$ Juan Kumpel, González's personal adviser, was of German extraction and was allegedly persuading González to the German cause. William J. Price, March 14, 1917, D. S. File $818.00 / 116$.

32 Castro Quesada to Lansing, February 28, 1917, Foreign Relations, 1917, pp. 309-312.

${ }^{33}$ Hale to Lansing, March 15, 1917, D. S. File 818.00/116; Hale to Lansing, April 15, 1917 , D. S. File $818.00 / 130$.
} 
Union, advised Polk that since Tinoco had the support of all the factions, the revolution appeared to be more significant than the ambitions of one man. ${ }^{34}$ Moreover, despite Oreamuno's tirades that Tinoco was committing an "abominable treason," the ex-presidents were stilll wholeheartedly supporting him as truly a man of the people. ${ }^{35}$ Their insistence posed a difficult problem when, on April 2, 1917, Tinoco was overwhelmingly elected president. ${ }^{36}$

Wilson remained resolute and could afford to do so. Tinoco did not gain the support of the American press which devoted its attention to World War I. In less harrowing times, his cause would have been grist to at least some of the opposition Republican newspapers. ${ }^{37}$ Nor did Tinoco's sympathy with the American cause in the war sway Wilson', who first of all did not really need his support to win the war but who was so single-mindedly pursuing his non-recognition policy that he disregarded the possible dangers to his war policy, should Tinoco become belligerently anti-American and should sympathetic neighbors then back him. ${ }^{88}$ Although the American Senate passed a bi-partisan resolution urging Wilson to recognize Tinoco because of his war stand, that body did not follow through in attacking Wilson's policy because of its preoccupation with war measures. To be sure, Tinoco won some support in Europe and Latin America from nations that needed Costa Rican products and appreciated his declaration of war on Germany, but he lost much of this support when Wilson disapproved. ${ }^{39}$ Even when Hale appealed to Wilson's sense of humanity to alleviate the plight of the people, his pleas fell on deaf ears. Immediately after Hale's appeal, the minister was recalled. In April, 1917, the chargé d'affaires, Stewart Johnson, took over the legation and the dispatches became thereafter strongly anti-Tinoco. ${ }^{40}$

\footnotetext{
${ }^{34}$ Leo S. Rowe to Polk, March 27, 1917, Polk Papers.

${ }^{35}$ Oreamuno to Anderson, March 27, 1917, Anderson Papers; Hale to Lansing, March 29, 1917; Foreign Relations, 1917, p. 330.

${ }^{36}$ Stabler to Lansing, March 31, 1917, D. S. File 818.00/128; Hale to Lansing, April 2, 1917, Foreign Relations, 1917, p. 321.

${ }^{37}$ Anonymous, "Costa Rica's 'Coup d'état," Literary Digest, LIV (March 24, 1917), 810; The Nerw York Times, January 31, 1917, 10: 5; Entry of April 6, 1917, Anderson Diary.

${ }^{38}$ To be certain, Wilson did not have to fear the Central American nations, even if unified, but he would have been foolish to alienate them while fighting the World War. Tinoco to Wilson, April 11, 1917, Foreign Relations, 1917, p. 322.

${ }^{39}$ Hale to Lansing, April 15, 1917, D.S. File 818.00/130; Senate Resolution 362, in Congressional Record, 65th congress, 3rd session, p. 23.

${ }^{40}$ Hale to Lansing, April 18, 1917, D. S. File 818.00/134.
} 
Wilson had already launched a strong campaign to undermine Tinoco still further. The State Department responded to the presidential election by notifying both European and Latin American nations that the United States was intent upon the non-recognition stand." The administration also directed its fire on the United Fruit Company. The company had ceased its efforts towards obtaining recognition for the Tinoco government and was now on the defensive because the earlier refusal to permit Hale to use the wireless seemed disloyal. The State Department ignored the company's explanations and set upon a course by which it could destroy the support that Minor C. Keith was then rendering to Tinoco. ${ }^{42}$

As Tinoco's financial condition deteriorated, he became increasingly desperate. He continued to make overtures to Wilson by offering aid in the war. When these failed, he tried to soothe his discontented countrymen by appeals for patience. Soon he had no choice but to seek constitutional changes to strengthen his office. His congress not only opposed such changes, however, but also now became alarmed at the threat of dictatorship. ${ }^{43}$ Tinoco then alleged that the González family was threatening to seize the government. In desperation, Tinoco enlarged his secret police, curtailed newspapers, and sent his brother Joaquín to the United States for support and munitions. ${ }^{44}$

But while Tinoco was reaching the nadir of his misfortunes, he received unsolicited support in Washington from Lansing. As a result of an investigation conducted in Costa Rica by his nephew, John Foster Dulles, Lansing believed that he now had enough data to persuade Wilson to modify his policy. Dulles, who ostensibly had been traveling in Central America on behalf of Panama for the law office of Sullivan and Cromwell, had brought to Lansing a fairly impartial report which convinced the Secretary that he should risk Wilson's enmity by advo-

\footnotetext{
41 Stewart Johnson to Lansing, April 20, 1917, D. S. File 818.00/136.

42 The company based its stand upon a Costa Rican law which forbade the use of private facilities for official communications and upon the fact that the district manager of the company was not available to decide upon the exceptional case. State Department Memorandum by Stabler, February 24, 1917, D. S. File 818.00/127; Keith to Rowe, April 13, 1917, and Rowe to Polk, April 26, 1917, D. S. File 818.00/156; Entry of May 3, 1917, Anderson Diary; William Penfield to Lansing, May 15, 1917, D. S. File 818.00/149.

43 Johnson to Lansing, April 30, 1917, Johnson to Lansing, May 14, 1917, Foreign Relations, 1917, pp. 322-323; Entry of May 14, 1917, Anderson Diary; Monge Alfaro, Historia de Costa Rica, pp. 260-261.

${ }^{44}$ Correspondence is in Foreign Relations, 1917, pp. 323-325; R. Fernández Guardia to Lansing, May 31, 1917, D.S. File 818.00/163; Johnson to Lansing, June 2, 1917, Foreign Relations, 1917, p. 326.
} 
cating a departure from the curent policy..$^{45}$ Dulles had found that the revolution was solely an internal one, because González, though apparently honest and patriotic, had been egotistical, tactless, and impractical in his reform program. He denounced Tinoco's coup d'état as greedy and the subsequent election as fictitious, but he nonetheless advised recognition since Tinoco was strongly entrenched and proAmerican. Dulles stipulated, however, that the United States should send a strong representative, and that Tinoco should be required to return to a gold standard, draft a new constitution, and demonstrate good government afterward. ${ }^{46}$

Lansing, after paraphrasing Dulles' report, advised Wilson that the United States was in a "predicament." Though granting the merit of the non-recognition policy, he believed that the Costa Ricans had "practically acquiesced in the change." More important, he concluded that since Tinoco was pro-Ally, the United States would be assured of a friendly ruler near the Canal Zone. Finally, utilizing the conclusion of Dulles (which was reminscent of Hale), he believed that recognition was vitally necessary to restore confidence in the government and thus alleviate the financial distress of the people. Therefore, from the "standpoint of expediency," he considered recognition of Tinoco to be "probably the best policy." 47

Lansing's effort was ineffective; Wilson flatly refused to recognize Tinoco because of expediency. He reiterated to the Secretary that the United States opposed all revolutions and wished all to know it. ${ }^{48}$

Lansing had no choice, in view of his realistic appraisal, but to persist in his course by other means. Taking the further advice of Dulles, he sought to induce Tinoco to retire and to permit the formation of a provisional government. He emphasized to Tinoco that Wilson was unmoveable. But Tinoco proved to be just as stubborn as Wilson; he replied that though recognition was desirable, it was not essential. ${ }^{49}$

Despite this expression of defiance, Tinoco was in great difficulty.

\footnotetext{
45 Entry of April 28, 1917, Anderson Diary.

${ }^{46}$ Dulles to Lansing, May 1, 1917, D. S. File $818.00 / 142$.

${ }^{47}$ Lansing enclosed both Dulles' report and a letter of General E. H. Plummer who urged recognition of Tinoco because of the Canal Zone. Lansing to Wilson, May 23, 1917 , D. S. File $818.00 / 200$.

${ }^{48}$ Wilson to Lansing, May 28, 1917, D. S. File 818.00/196.

49 Entry of May 28, 1917, Anderson Diary; State Department Memorandum by Stabler, June 12, 1917, D. S. File 818.00/184; State Department Memorandum by Dulles, May 29, 1917, D.S. File 818.00/197; Lansing to Johnson, May 29, 1917, D. S. File 818.00/162a; Johnson to Lansing, June 15, 1917, Foreign Relations, 1917, pp. 327-328.
} 
Desperately in need of funds, he was prepared to resort to the printing press when Minor Keith, fearful of the consequences of inflation, offered to formulate a more sensible and sound financial program..$^{50}$ Wilson was astounded by this development, and he directed Lansing to send Keith " a very solemn warning" that the United States would seek to nullify any resulting contracts. ${ }^{51}$

Disregarding Washington's admonitions, Keith proceeded with his program and brought some temporary relief to the economy. A coffee export tax was passed; concessions for meat-packing were introduced in the congress; and a manganese shipping contract was negotiated. ${ }^{52}$ John Keith, hopeful at the turn of events, forecast Tinoco's recovery to the former minister, Hale, then living in Fayetteville, North Carolina. He held that intervention was the only course open to the United States. Commenting upon Wilson's policy, he made an apropos comparison: "A combined policy of non-recognition and non-intervention is a sort of a political Seidlitz powder, which makes a deuce of a fizz and the wrong party takes the medicine." ${ }_{53}$

Wilson ordered immediate action to undermine both Keith and Tinoco, but the State Department could do little. Legal action was instituted against the United Fruit Company, but nothing resulted immediately from this. ${ }^{54}$ Afterward, the Department seemed to have reached the end of its resources. Dulles even forecast that Tinoco would become stronger, not only because of his new sources of revenue, but also because he had secured friendlier relations with his neighbors. ${ }^{55}$ The Office of Naval Intelligence, anxious to insure the friendship of a country so near the Panama Canal, advised the State Department that the policy was "ridiculous and ineffective" not only because it was directed against an avowedly friendly nation but also because it was obviously fruitless. ${ }^{56}$ Nonetheless, Wilson was unmoved, although "Watchful Waiting" seemed to drag on endlessly."

Actually the situation was worse for Tinoco than it appeared on the

${ }^{50}$ Johnson to Lansing, July 18, 1917, ibid., pp. 339-340.

51 Wilson to Lansing, July 21,1917 , D. S. File $818.00 / 306$.

52 Johnson to Lansing, July 26, 1917, D. S. File $818.00 / 191$.

${ }^{53}$ Hale to Lansing, July 21, 1917, D. S. File 818.00/190.

${ }^{54}$ Lansing to Charles Parmelee of the Justice Department, August 10, 1917, Lansing Papers.

55 Dulles to Charles Warren of the Justice Department, August 27, 1917, D. S. File $818.00 / 234 a$.

56 Office of Naval Intelligence to State Department, August 23, 1917, D. S. File 818.00/ 231.

${ }^{57}$ Entry of September 11, 1917, Anderson Diary. 
surface. The State Department was having some success in undermining support for Tinoco among his neighbors. Panama, in order to appease the United States, had already agreed not to recognize the dictator. Nicaragua withheld recognition because of Tinoco's stand against the Canal Treaty. And Lansing again warned Honduras, Guatemala, and El Salvador that friendship with Tinoco would indicate unfriendly feeling towards the United States. ${ }^{58}$

Further signs of Tinoco's weakness were also appearing. Other American investors in Costa Rica, both in agriculture and in mining, became jealous and resentful of Keith's influence and repudiated his financial program. Even the Keith interests realized that they alone could not sustain Tinoco, and they urged the Costa Ricans to bear with the government during the crisis. They sent repeated appeals to American senators, stressing Costa Rica's pro-Ally stand in the war and the unfortunate economic plight of the people who depended upon the full commercial intercourse with the United States. They persuaded Senator Henry Cabot Lodge to espouse their cause. Lodge urged Lansing to extend recognition, but his appeal was too weak to be effective. $^{\text {so }}$

Although Tinoco managed to retain power until the summer of 1919 , his declining strength invited counterrevolutionary movements in the year and a half that he was to linger precariously in power. Beginning in the final months of 1917 , so many reports of counterrevolutionaries in bordering nations came into the State Department that Lansing had to warn Honduras and Nicaragua not to violate the Washington Convention of 1907 by aiding them. Both the elder statesman Luis Anderson and the political opportunist Alfredo Volio Jiménez sought American support for a counterrevolution. ${ }^{60}$ These plots seemed to be an inevitable result of "Watchful Waiting," both in Mexico and Costa Rica, despite the anti-revolutionary purposes of Wilson's policy. ${ }^{81}$ Paradoxically, the Volio plans appealed to Wilson, who wrote to Lansing:

${ }^{58}$ Lansing to Leavell, September 21, 1917 (mutatis mutandis to Tegucigalpa, Managua, San Salvador), Foreign Relations, 1917, p. 343; Johnson to Lansing, October 8, 1917, D. S. File $818.00 / 237$.

${ }^{59}$ Johnson to Lansing, October 21, 1917, D.S. File 818.00/244; Lodge to Lansing, November 13, 1917, D. S. File 818.00/258.

${ }^{60}$ Johnson to Lansing, October 27, 1917, D.S. File 818.00/243; State Department Memorandum by Glenn Stewart, December 4, 1917, D. S. File 818.00/360; Johnson to Lansing, December 14, 1917, D. S. File 818.00/270; Senate Document, No. 77, 66th congress, 1st session.

${ }^{61}$ Lansing to Senator Joseph Ransdell, December 24, 1917, D. S. File 818.00/302a. 
To have anything at all to do with it is certainly to play with fire and to risk incurring the suspicion of every state in Latin America; and yet, if the man is sincere, what he purposes (always provided his programme does in all good faith include a free and constitutional election) must of necessity claim our sympathy. ${ }^{82}$

Was Wilson's support of a counterrevolution the only alternative to his policy? Wilson thought it to be a possible solution, but Lansing vigorously opposed expressing sympathy toward Volio. He advised Wilson that though the non-recognition policy was preventing true hemispheric solidarity, nothing else should be attempted. Wilson concurred. $^{\text {es }}$

In Washington, representatives of both González and Tinoco continued to try to sway Wilson. Among the important incidents in the subsequent lobbying was William J. Bryan's attempt to obtain support for Tinoco. Tinoco's chief agent Carlos Lara had successfully convinced Bryan that Tinoco was the rightful president and that the longer recognition was withheld, the longer the Costa Rican people would suffer under a weak government. Bryan attempted to intercede with Wilson through Lansing. Wilson vainly tried to dissuade Bryan through mutual friends, and he was afterward pained to hear of Bryan's persistence. ${ }^{84}$

The investigation of the United Fruit Company also desultorily continued. Minor Keith emphatically denied any complicity in the revolution, and although the State Department could not find sufficient evidence to indict Keith, it nevertheless considered making a full investigation of all Americans suspected of aiding Tinoco. Wilson agreed that a confidential effort to check on them was necessary, noting that, "We cannot go too far in bagging such disloyal men." In the end, despite the quite possible justice of the administration's allegations, no legal charges could be brought against any person. ${ }^{85}$

62 Wilson to Lansing, December 29, 1917, The Lansing Papers, II, 521.

${ }^{63}$ Lansing to Wilson, December 31, 1917, ibid., pp. 521-522; Wilson to Lansing, January 1, 1918, ibid., p. 522.

${ }^{64}$ Polk to Wilson, July 18, 1918, Polk Papers; Entry of September 3, 1918, Josephus Daniels Desk Diary, Library of Congress; State Department Memorandum, September 19,1918, D. S. File $818.00 / 496 \frac{1}{2}$.

65 Polk to Wilson, January 11, 1918, Woodrow Wilson Papers (hereafter cited as Wilson Papers), Library of Congress; Lansing to Wilson, May 15, 1918, D. S. File 818.00/ 492; Wilson to Lansing, May 20, 1918, D. S. File 818.00/493. It is important to add that the origin of the revolution has also been traced to the Costa Rica Oil Corporation which supported Tinoco because of González' opposition to monopolistic concessions. State Department records did not allude to this corporation, nor did any American official mention it. Raúl de Cárdenas y Echarte, La Política de Los Estados Unidos en 
Throughout 1918 Washington could do little except to await developments. The last significant action taken against Tinoco was the closing of the American legation in protest against the brutal quelling by police with sabers of a pro-American demonstration outside the legation. Chargé Johnson was recalled, but the State Department directed the American consul, Benjamin Chase, to keep open his office for American citizens and also to serve as the eyes and ears of the Department in San José. ${ }^{86}$

Of the further problems attending "Watchful Waiting," one of particular note was the alleged threat of Tinoco to harm Consul Chase. Chase was reporting regularly on Tinoco and feared personal reprisal for doing so. After notifying the Department that Tinoco had threatened him several times and that he believed that troops should be landed to protect American life and property, the consul was informed by Polk that he was " rattled and he must keep cool." There may have been some substance to Chase's fear because, soon afterward, Tinoco demanded that Chase be put in jail as one of the conditions of his withdrawal from power. ${ }^{07}$

In June, 1919, Tinoco presented his conditions for resigning, since his downfall appeared to be imminent. Essentially he offered to stand aside for one of his lieutenants. Naturally, Wilson would not tolerate this, nor indeed would he be satisfied with anything less than the absolute end of the Tinoco dictatorship. However, his policy was now complicated because the United States Senate was able, now that the World War was over, to vociferously condemn his adamant stand. Earlier the Senate had approved Tinoco's declaration of war against Germany by resolving that he should be recognized as an ally, but had either lacked time or had chosen not to follow through against Wilson's policy. During the committee hearings on the Versailles treaty however, the committee reproved Wlison for refusing to permit Costa Rica to attend the peace conference in Paris. Wilson and Lansing retorted that since Costa Rica had not been recognized, it was not a war partner. Fortunately for them, the senators again did not see fit to pursue the matter..$^{88}$

el Continente Americano (La Habana, 1921), p. 261; and Monge Alfaro, Historia de Costa Rica, pp. 255-256.

${ }^{66}$ Johnson to Lansing, November 14, 1918; Lansing to Johnson, November 26, 1918, Foreign Relations, 1918, pp. 272-275.

${ }^{67}$ Entry of June 15, 1919, Polk Diary; Polk to Lansing, June 25, 1919, Lansing Papers.

68 Wilson to Lansing, June 27, 1919, Lansing Papers; Congressional Record, 65th congress, 3rd session, p. 23; Senate Document, 106, 66th congress, 1st session (Washington, 
In any event, it was too late for Tinoco. Two months earlier, in May, 1919, Julio Acosta García, who, upon Alfredo Volio's natural death, succeeded as head of the counterrevolutionary movement, had crossed the Nicaraguan border with a small revolutionary force. This force formed a nucleus of opposition that drew the public, now desperate because of the economic and political oppression, into a united front against Tinoco. Although Tinoco, retaining control of the army, held out until August, he finally despaired when his brother Joaquín was assassinated. On August 12, 1919, at the behest of the diplomatic corps, which feared further repercussions, Federico Tinoco resigned and fled to Kingston, Jamaica. ${ }^{69}$

Wilson was not pleased when a Tinoco lieutenant, Juan Bautista Quirós, the first designate, succeeded to power. Because the succession came under the "invalid" Tinoco constitution, the State Department successfully put pressure on the new president to resign in favor of Federico Aguilar Barquero, a designate elected before Tinoco's ascendancy. When Aguilar Barquero promised to hold elections, the Latin American Division unanimously recommended extending immediate recognition in order that the temporary government could win international respect and that commerce could resume without the residual fears of Wilson's injunctions against concessions. Lansing agreed and so informed Wilson. When Wilson did not respond, probably because of illness, Lansing turned to the president's secretary, Joe Tumulty, for his intercession. But even Tumulty apparently could not by-pass the president's wife, Edith Bolling Wilson, who was guarding the careworn, physically stricken president against outside intrusions.

After Julio Acosta was duly elected president in December, 1919, Lansing again appealed to Wilson to extend recognition pending Acosta's assumption of power. Again he failed. ${ }^{70}$ After Lansing resigned in February, 1920, Secretary of State ad interim Frank Polk also vainly promoted immediate recognition even though Acosta would not be inaugurated until May. He also failed. ${ }^{71}$ When Bainbridge Colby, whose only qualification for the secretaryship was his friendship with

1919); Wilson to Lansing, August 5, 1919, D. S. File 818.00/807; Wilson to Lansing, August 8, 1919, Wilson Papers.

${ }^{69}$ Chase to Lansing, August 11, 1919, and vice-consul Montgomery to Lansing, August 12, 1919, Foreign Relations, 1919, pp. 850-851; Monge Alfaro, Historia de Costa Rica, pp. 273-274.

70 Lansing to Wilson, December 13, 1919, D. S. File 818.00/955a.

${ }^{71}$ Polk to Wilson, March 4, 1920, D. S. File 818.00/963a. 
Wilson, took over, he was urged by Leo S. Rowe, then Chief of the Latin American Division, to take up recognition with the president. Whether or not Colby, who showed no awareness of the tragedy of the situation, urged recognition, did not matter, for the president still took no action. ${ }^{72}$ Even when Acosta was inaugurated in May, and Norman Davis, the undersecretary of state, urgently recommended recognition Wilson did not act. Not until August 2, 1920, was recognition extended..$^{73}$

Only two explanations for Wilson's hesitancy appear plausible. He may have been too ill to consider the matter, although after November, 1919 , he was probably not too incapacitated to have responded in a simple affirmative or negative. Possibly, the notes of the State Department were not delivered to him during his illness. A more probable explanation may have been that Wilson wished to assure himself that the duly elected president would assume power and that afterward he would be able to retain it.

Wilson's non-recognition policy, because of Tinoco's tenacity, proved to be not only largely ineffective in promoting stable and constitutional regimes in the Caribbean, but even harmful. His self-righteous meddling to achieve utopian ideals and the peaceful solution to Caribbean revolutions backfired. Both the self-interest of the United States, in that cooperation of the Central American republics was needed to insure the security of the Caribbean area against German inroads, and aspects of the situation, in that many innocent Costa Ricans materially suffered, required the recognition of the Tinoco government. It would seem that Wilson was so obsessed by his moral vision of democratic and constitutional government that he ignored the effects of his policy. Wilson had employed both diplomatic and economic power to reach an objective perhaps not morally unpraiseworthy; but, in so doing, his single-minded approach contributed to the economic plight of the Costa Rican people, caused disharmony within his own administration, and perpetuated political uncertainty in a nation of strategic importance to the United States in time of war.

Rensselaer Polytechnic Institute,

George W. Baker, Jr. Troy, New York

\footnotetext{
72 Rowe to Colby, April 6, 1920, D. S. File 818.00/1027; Daniel M. Smith, "Bainbridge Colby and the Good Neighbor Policy, 1920-1921," The Mississippi Valley Historical Review, L, No. 1 (June, 1963), 56-78.

${ }^{73}$ Davis to Wilson, June 25, 1920, Wilson Papers; Colby to Chase, August 2, 1920, Foreign Relations, 1920, I, 834.
} 